\title{
Bacillus subtilis
}

National Cancer Institute

\section{Source}

National Cancer Institute. Bacillus subtilis. NCI Thesaurus. Code C86167.

A species of aerobic, Gram-positive, rod shaped bacteria assigned to the phylum

Firmicutes. This species is motile, spore forming, catalase and superoxide dismutase positive, indole negative, and reduces nitrate, hydrolyzes starch, and does not ferment glucose or lactose. B. subtilis is found in the soil and is used in the commercial production of enzymes and antimicrobial compounds, for testing sterilization techniques and can be used as a probiotic in healthy individuals, but can be pathogenic in those that are immunocompromised. 